\title{
Students' Attitudes on the Teaching of Christian Religious Education in Secondary Schools in Kenya
}

\author{
Kasomo Daniel \\ Maseno University,Private Bag,Maseno,KenyaDepartment Religion,Theology and Philosophy
}

\begin{abstract}
This paper attempts to find out the impact of teachers and students' attitudes on the teaching of Christian religious education in Machakos secondary schools. The purpose of the investigation is to explain the attitudes of teachers and students with a view to drawing conclusions, which would be recommended for improving the status of Christian religious education (CRE) in secondary schools. This paper is based On study undertaken in Machakos secondary schools in Kenya. Sampling procedure in order to allow a regional representation of implementers and consumers of CRE in Machakos secondary schools. The study employed open and closed questionnaire administered to all the participants; an interview done in nine secondary schools among nine teachers and twelve students and an observation of CRE documents affected in eight schools. The attitude scores derived from the closed questionnaire were analyzed using factor analysis, descriptive statistics, chi-square tests and one and two analyses of variance. The open responses were subjected to content analysis and some chi-square tests for the categorized data. The attitude scale as the chief instrument in data collection had a high cronbach alpha of 0.9 a mean of 72 and standard deviation of 15.Based on the analysis, this paper contends that there are no significant differences among respondents of different backgrounds in their attitudes towards CRE. The respondents' conception of the nature of CRE falls in two groups: a positive oriented group which contends that CRE has utilitarian value and the other group that view CRE as non-functional. In conclusion it is argued that any recommendations for improving CRE have to be directed towards clarifying CRE objectives. Thus, the key recommendation points for a need to have CRE as part of an integrated Religious Education (RE) programme whose main aim should be to lead students towards being religiously educated.
\end{abstract}

Keywords Attitude, Christian, Education, Religion

\section{Introduction}

During the colonial era CRE featured as a dominant school subject(Anderson, 1979: Ayot, 1986). Missionaries used it as a tool to win converts. Currently, the subject has an optional status for both teachers and students. It is also being challenged by socio-economic conditions which have consistently demanded a functional programme to meet the needs of a developing nation rich in religious plurality, diversity and secularity. Consequently, this raises concern on the future of CRE. One wonders whether CRE will survive the onslaught of modernization, religious plurality, and secularity and stiff competition from other humanities. This situation has necessitated the need to empirically search, review and evaluate the subject's value and worth from the approach and undertaking of those implementing supervising and consuming it.

\subsection{Objectives of the Study}

* Corresponding author:

dkasomocounselling@yahoo.com (Kasomo Daniel)

Published online at http://journal.sapub.org/ijpbs

Copyright (C) 2011 Scientific \& Academic Publishing. All Rights Reserved
This study tried to establish and explain the status of CRE as perceived by teachers and students in the multi-cultural and religious Kenya society. It poses the question; does CRE fulfill its present and future and educational role as judged by its teachers and students? The assumption is that the subject is worth having for what it is, an educational subject at all levels of learning. This study has addressed teacher and students' attitudes to the subject and was guided by the following research questions:

- What are the attitudes of teachers and students towards the nature of CRE?

- What factors explain the attitudes of teachers and students towards CRE in Kenya secondary schools?

- In carrying out this study, the variables of

- Age,

- Gender,

- Academic and professional qualifications,

- Teaching experience,

- Religious affiliation and

- The kind of School

Is used as the explanatory factors of the phenomenal attitudes to the nature of CRE. Burgess(1986) also identified some of these social factors as explanatory variables, which could be employed to distinguish people. 


\subsection{Attitude Concept}

It is imperative that we clarify meaning of the term attitude. As a concept, attitude is an elusive term. Any definition of attitude shows that it is a hypothetical construct that is not tangible, but has to be inferred from the world or experience (Thurstone,1928). This implies that attitude is an index of an individual's thoughts and feelings about people, objects and issues in the environment(Ajzen,1988; Deaux, et al. 1993). Thus, attitudes are crucial in understanding the way people perceive the world around them, as they determine what a person will see and hear and think and do, thus making them central to life(Jahoda and Warren, 1966; Oppenheim, 199; and Oskamp,1977). In this context attitude formation and change is an important part of identifying and explaining an individual's attitude to an object or issue

Various attitude formation and change theories like functional theory(Katz, 1960 and Sarnoff,1960), cognitive dissonance theory(Festinger,1957), learning behaviouralist theory (Hovland,1953) and social judgement of attitude change theory( Sherif and Sherif,1967). Have been postulated. Each of the attitude change theories suggests that attitudes are not inherited, rather, they are learnt, changed and could be investigated. The functional model theory was chosen to form the theoretical framework for this investigation. The theory mainly associated with(Katz,1960 and sarnof,1960) stipulates four major functions of attitudes:

- $\quad$ Adjustment function;

- Ego defensive function;

- Value expressive unction and

- Knowledge function.

The theory argues that changing of existing attitudes involves destroying the capacity of existing attitudes by making their functions unattractive. Consequently existing attitudes could be explained by their functions

\section{Research Methodology}

\subsection{Research Design}

The investigation has employed both quantitative and qualitative methods in an ex-post facto design. This approach provides an understanding of Kenyan CRE from restricted responses to free, undetermined and varied open responses. The outcome has been numerous data that were subjected to statistical and content analysis techniques.

\subsection{Sampling Procedures}

The sample comprised 37 secondary schools teaching CRE from form one to four. Using an administrative map of Machakos District, the schools registered for 2008 Kenya certificate of secondary examination(KCSE) CRE were categorized into six geographical zones with their towns as point of accessibility. To maintain the confidentiality of the schools, each school was identified by a number.

\section{Target Population}

The participants comprised teachers as a focus group that had gone through the CRE programme as student and presently as implementers and supervisors. The study assumed that they were knowledgeable and could easily identify weak areas of the subject(CRE), which require adjustments and changes. Form three students represented secondary school students because at the end of form two, they opted for CRE in the Kenya certificate of secondary education examinations. In addition, they have benefited from two years exposure to the subject. In this case, they could be in a position to indicate, evaluate and project whether CRE is fulfilling their needs or not.

\section{Measurement Designs}

The questionnaire used ran from low-level difficulty through items to the open-ended question of high-level difficulty. The first section of the questionnaire had questions on the demographic data. The respondents were required to indicate their background characteristics. They were used as explanatory variables. Honesty and truthfulness were encouraged from all respondents by assuring them that any information they gave was to be treated confidentially.

The attitude scale, in Likert format, formed the second section of the questionnaire. This design was adapted because of its emphasis on precise and specific question (Francis, 1984 and oppenheim, 1992). Thus, information from a large number of participants was obtained taking up relatively little time and using a standard form which may mitigate interviewers' bias(Vermon, 1964).

The present structural model of CRE in Kenya secondary schools was used to state items. Various items were based on issues arising from literature review, discussions with colleagues on the subject and my experience in teaching CRE at all levels of Kenya's education system. This ensured that the attitude statements were framed in the teachers' and students' concepts and language.

Responses on the attitude scale for each of the statements ran from strongly agree, through agree, disagree to strongly disagree. These four points were given simple weights of $4,3,2,1$ and 0 to no answer, for scoring purposes. The neutral point was omitted so as to accord respondents an opportunity to identify with the attitude from the continuum.

The final section of the questionnaire was a kind of follow up from the close attitude items. The section was rather demanding in that respondents had to provide their own unguided responses, which were crucial in facilitating the explanation and interpretation of the rest of the data. A set of questions related to various dimensions of the subject was used to give respondents an opportunity to express their understanding and evaluation of the subject's tasks currently and in the future.

Apart from the questionnaire, the study had also employed interviews. This approach gave participants an opportunity to provide meaning and perspectives they attach to their attitudes towards CRE.(Hammersley and Artkinson,1983) 
correctly observed that the aim of interview:

is not to gather pure data that are free from potential bias. There is no such thing. Rather the goal must be to discover the correct manner of interpreting whatever data we have (p.12)

The interview schedule was used because of its flexibility in allowing deep probing respondents by pursuing their responses(Fraenkel and Wallen, 1996; Wiersma, 1989). May(1993) commends interviews because they provide "rich data on people's experiences, opinions, aspirations and feelings" being limited, in that very few participants $(\mathrm{n}=21)$ were interviewed, the method was used to supplement results obtained from the questionnaires.

The schedule process guide was checked by two religious education lecturers at catholic University of Eastern Africa to ensure its clarity, relevance, applicability and validity in all aspects. The interview process schedule had three main sections to which respondents were required to respond orally, while their responses were tape recorded simultaneously. The tape recorder retained the entire communication for analysis and reference(Bagdan and Biklen, 1992). To ensure that the respondent understood the purpose of the research and the questions direct to him/her, rapport was built and maintained to keep the respondent interested in the issues raised(Oppenheim, 1992). The tone of the interviewing was conversational, as "conversation is by far the most economical means, in terms of time and effort, of arriving at a valid assessment of a situation(shipman, 1976:32)

To further understand the teachers and students of CRE, I conducted some observation of the school environment. Initially, I had organised for staged CRE lessons, but this did not materialise because of the limited time and tight school schedules. However, in eight sampled schools, the key documents connected with the subject were observed and analysed using an adapted documentary summary form recommended by Miles and Huerman,(1994). The documents observed included: the 1992 CRE syllabus KIE,(1992) textbooks Davin,(1989) groenewegen, 1988 Groenewegen, et al (1986) Groenewegen and Githige,(1987),(1988) Groenewegen and Wanjala, (1989) Kerr an Manyore,(1995) Levi,(1983)(1989) Masolo,(19900 welch and Wild,(11986, 1987 b; 1988),Schemes of work lesson notes; lesson plans, records of work, progress records, students' exercise books, test papers and marking schemes. The information from the documents was summarised in some already prepared forms as photocopying facilities were not available. The data obtained in this inanimate approach strengthened the rest of the data.

\section{Data Collection Procedures}

Questionnaires were personally distributed and collected. Direct contact with schools allowed instructions on how to complete the questionnaires and assure the respondents the confidentiality of their responses. This personal involvement was an important factor in motivating the participating schools to respond more readily than if the questionnaires had been mailed to them. Interviews and observation of documents were done on the day and time agreed upon with the CRE teacher.

Data analysis and emerging issue

After basic frequency checks, facto analysis was run on the 56 attitude item to establish the scale's validity, reliability and parsimony. An unidimensional scale model comprising 54 items and having cronbach alpha of 9.4 was obtained. In undertaking further analysis, items one and five were removed from the scale as they did not fulfill Kaiser's criterion of 0.3 loading with principle components.

Responses to the 54 attitude items were assigned values of 4, 3, 2 ad 1 for strongly agree, disagree and strongly disagree respectively. These values were reversed for negative attitude items so that high scores always indicated positive attitude, while low score represented negative attitude to the nature of CRE.

All respondents' scores were standardized to level and spread of 0 to $100 \%$ using the formula(x-54)(162/100). X stood for each case's total score, while 54 which was a level value was subtracted from $\mathrm{x}$ so that a zero level was obtained for the

The results were then divided by $162 / 100$ a value of spread, based on 100, a convenient level. All scores ended up ranging from 0 (negative attitude) to 100 (positive attitude). Individual attitude scores ranged from 4 to 100 . The scale's mean was 72 and had a respondents' attitude scores were Leptokirtic and negative skewed.

Chi square tests plus Cramer's V correlation coefficients were carried out to establish whether the attitude scores frequencies were significantly associated with the respondents' background. There were 336 chi square tests done on teacher and only about $2 \%$ were significant. For students, 270 chi square tests were run and only 67 showed significant relationship at 0.05 levels of significance. However, most of the chi square results were not substantive as their Cramer's $\mathrm{V}$ correlation co-efficient were rather low( 0.1 to 0.5$)$ this indicates that the relationship between the attitude score and the respondents background may not be substantively significant.

One-way analysis of variance accompanied by Turkey-b tests were computed to determine whether the different group means were significant or not where the differences were. The teachers mean scores of different backgrounds were not significantly different. Similarly, school 14 which differed significantly with 17 other schools in the sample had its different group's mean scores not significantly different. However, gender, religious group and school factors had main effects in students' mean groups(table 1). The significant results in one-way analysis of variance were subjected to two-way analysis of variance to establish the interaction effect of gender, school and religious group factors. It was only religious group and school factor design, which indicated some, limited interaction effects. This interaction ef- 
fect explained only about $35 \%$ of the variance in the means (table 2). The implication here was that there was likehood of other factors to explain in the residual variance $(65 \%)$. This led to search for other explanatory factors from the qualitative data.

Table 1. Students' one-way analysis of variance results

\begin{tabular}{|c|c|c|c|}
\hline Variable & Df & F ratio & Probability \\
\hline Gender & 1 & 5.04 & 0.03 \\
\hline Age & 2 & 1.53 & 0.22 \\
\hline Religious groups & 5 & 4.23 & 0.00 \\
\hline Marks & 7 & 1.38 & 0.21 \\
\hline Grade & 7 & 1.37 & 0.22 \\
\hline School & 27 & 4.86 & 0.00 \\
\hline
\end{tabular}

Open responses were categorized in terms of frequency distributions obtained. Chi Square and contingency co-efficients were computer on the open-responses frequencies from the questionnaire to determine whether they were related to respondents' background characteristics. The chi square results were not substantive as they had rather low contingency co-efficients $(0.0$ to 0.5$)$. Thus, the responses and the respondents' backgrounds were independent.Consequently, the actual raw responses from the open-ended questionnaires, interviews and documentary analysis were content analyses to provide respondents' imprints on the issues raised.

From the raw responses other variables, which could account for some of the variability in the responses emerged.
For instance, the impact of school administration was given a key facto by school 14. Comments from school 14 showed how some students did not wish to do CRE, which they regarded as not being useful, but were forced by the school administration. One student, when interviewed why she decided to do CRE responded that:

Initially there were only 11 students who wanted to do CRE. I was not one of them. The headmistress made it compulsory it was not my choice to do CRE. I do not get good marks... saying that it was the wish of the school sponsors that CRE be compulsory. I did not want to continue on it after form two... I find it not useful in any way. I am just designer or actress...I do not need CRE for this(case KS2)

In observing one of the students' CRE exercise book, next to a score of $6 / 20$ were comments in pencil by the student: "rubbish! To hell with it" the teacher's comments on this assignment for this student were "you need to read more on the topic".

It is obvious from these comments that the respondents' conception of the nature of CRE seemed to emerge as a factor to use in trying to explain the nature of the respondents' attitudes. In fact, one group appeared to argue that CRE has no utilitarian value. The second group would not see why CRE should not be made compulsory because of its use in personal development. There two views could be illustrated by the respondents' comments outlined hereunder.

Table 2. Students' two-way analysis of variance results on gender, religious group and school

\begin{tabular}{|c|c|c|c|c|c|c|}
\hline Source of variation & & Sum of squares & $\mathrm{df}$ & Mean squares & $\mathrm{F}$ & Significance of $\mathrm{F}$ \\
\hline Covariate & ralaffi & $\begin{array}{l}1378.3 \\
1378.3\end{array}$ & $\begin{array}{l}1 \\
1\end{array}$ & $\begin{array}{l}1378.3 \\
1378.3\end{array}$ & $\begin{array}{l}7.5 \\
7.5\end{array}$ & $\begin{array}{l}0.006 \\
0.006\end{array}$ \\
\hline Main effects & $\begin{array}{l}\text { Gender } \\
\text { school }\end{array}$ & $\begin{array}{c}28401.0 \\
287.9 \\
227224.8\end{array}$ & $\begin{array}{c}28 \\
1 \\
27\end{array}$ & $\begin{array}{c}1014.3 \\
287.9 \\
1008.3\end{array}$ & $\begin{array}{l}5.5 \\
1.6 \\
5.5\end{array}$ & $\begin{array}{c}0.000 \\
0.21 \\
0.000\end{array}$ \\
\hline 2-way interactions & $\begin{array}{l}\text { Gender } \\
\text { School }\end{array}$ & $\begin{array}{l}569.4 \\
569.4\end{array}$ & $\begin{array}{l}7 \\
7\end{array}$ & $\begin{array}{l}81.3 \\
81.3\end{array}$ & $\begin{array}{l}0.4 \\
0.4\end{array}$ & $\begin{array}{l}0.9 \\
0.9\end{array}$ \\
\hline Explained & & 30348.7 & 36 & 843.0 & 4.6 & 0.000 \\
\hline Residual & 100433 & 547 & 183.0 & & & \\
\hline Total & 130781.7 & 583 & 224.3 & & & \\
\hline Covariate & school & $\begin{array}{l}1429.9 \\
1429.9\end{array}$ & $\begin{array}{l}1 \\
1 \\
\end{array}$ & $\begin{array}{l}1429.0 \\
1429.9\end{array}$ & $\begin{array}{l}6.7 \\
6.7 \\
\end{array}$ & $\begin{array}{l}0.010 \\
0.010\end{array}$ \\
\hline Main effects & Gender relaffi & $\begin{array}{c}6382.8 \\
973.8 \\
5242 \\
\end{array}$ & $\begin{array}{l}6 \\
1 \\
5\end{array}$ & $\begin{array}{c}1063.8 \\
973.8 \\
1048.4 \\
\end{array}$ & $\begin{array}{l}5.0 \\
4.5 \\
4.9 \\
\end{array}$ & $\begin{array}{c}0.00 \\
0.033 \\
0.00 \\
\end{array}$ \\
\hline 2-way interaction & & 576.67 & 5 & 115.3 & 0.5 & 0.748 \\
\hline & Gender relaffi & 576.6 & 5 & 115.3 & 0.5 & 0.748 \\
\hline Explained & & 8389.2 & 12 & 699.1 & 3.3 & 0.000 \\
\hline Residual & & 122392.5 & 571 & 214.3 & & \\
\hline Total & & 130781.7 & 583 & 224.3 & & \\
\hline Covariate & gender & $\begin{array}{l}1801.9 \\
1801.9\end{array}$ & $\begin{array}{l}1 \\
1\end{array}$ & $\begin{array}{l}1801.9 \\
1801.9\end{array}$ & $\begin{array}{l}10.5 \\
10.5\end{array}$ & $\begin{array}{l}0.001 \\
0.001\end{array}$ \\
\hline Main effects & $\begin{array}{l}\text { School } \\
\text { relaffi }\end{array}$ & $\begin{array}{c}30079.3 \\
2452.9 \\
2366.8 \\
\end{array}$ & $\begin{array}{c}32 \\
27 \\
5\end{array}$ & $\begin{array}{c}940 \\
908.3 \\
473.4\end{array}$ & $\begin{array}{l}5.3 \\
5.3 \\
2.7\end{array}$ & $\begin{array}{l}0.000 \\
0.000 \\
0.018\end{array}$ \\
\hline 2-way interactions & $\begin{array}{l}\text { School } \\
\text { relaffi }\end{array}$ & $\begin{array}{l}1391.6 \\
1391.6\end{array}$ & $\begin{array}{l}55 \\
55\end{array}$ & $\begin{array}{l}254.4 \\
254.4\end{array}$ & $\begin{array}{l}1.5 \\
1.5\end{array}$ & $\begin{array}{l}0.017 \\
0.017\end{array}$ \\
\hline explained & & 45972.8 & 88 & 521.3 & 3.03 & 0.000 \\
\hline residual & & 84909 & 495 & 171.5 & & \\
\hline Total & & 130781.7 & 583 & 224.3 & & \\
\hline
\end{tabular}


- CRE should be taught to those who want and not make it compulsory. It should be abolished. If it remains, let it.

- Be more on day-to day Christian experiences. Bible references should be abolished if it does remains. I hate CRE because I was forced to take it and would be glad if it was abolished(student 693)

- It is of no use because it is full of stories. It would be better if it was incorporated in history lesson (teacher 831)

- CRE enables me to be conscious of my destiny as man. It explains most of the questions that puzzle me. It a source of light to me(Teacher 811)

- It should be compulsory in schools, it should not be an option with other subjects so that it may improve our moral values particularly us youth(student 300 )

The positive group viewed the subject in terms of its usefulness, relevance and applicability in personal development, vocational training and improving the final grade in Kenya certificate of secondary education(KCSE). This view often predominated by undue textbooks and learning methods they liked. They desired relevant, less difficult, less broad and less repetitive topics. For instance, their preferred books had successful examination luring titles like Gold medal CRE KCSE(Davin,1989; top mark series CRE KCSE revision Kerr and Manyore, 1995 and gateway secondary revision CRE masolo,1990)

The negative oriented group viewed the subject as useless, irrelevant and inapplicable in life. There were 41 respondents(40 students and one teacher) who dismissed CRE as useless in life. Some even contended that the subject should be abolished from secondary school curriculum. In fact, the respondent who had the lowest attitude score(4) was among the 41 who saw no value in CRE.

The above conflicting views of teachers and students seem to rest on the functions of CRE. Respondents may be in situations where they may be asking: what does one get from teaching and learning CRE? This could imply that specific CRE objectives may be unclear to the respondents. To this extent, misconceptions manifest the respondents, general view of education. According to $\operatorname{Katz}(1960)$ both knowledge and misinformation serve a similar purpose in attitude formation and change. This explains why students and teachers seem to have value references on which their views cling. And, the information they have respondents recommended that CRE should be excluded from the school curriculum. This could mean that education on the world outlook that handles the realm of ultimate reality and being is not necessary while most of the society's values are predicated on it. Again, not to have CRE could also imply a kind of violation of religious liberty.

\section{Conclusions}

In this study the research process had been shifted from enumeration towards understanding and interpreting the social world in the respondents views. Frequency checks and frequent quotes have also been used to interpret what the respondents said. Thus, tapping qualitative, holistic, contextual and inductive aspects of attitude. This has given us a triangulation that embraced and strengths of each of the paradigms(quantitative and qualitative), to obtain more rich and useful data. A critical look at the attitude scale seems to suggest that respondents must be allowed to say something more. Open questions offered this opportunity to every respondent. The interview transcripts and documentary summaries' data provided supplementary details needed to understand the CRE world. Out of quantitative data emerged questions which qualitative data provided basis for elicitation. The use of techniques from both stances have effectively illuminated, enriched, and verified the results on the reality of what we have of CRE in Kenya secondary schools

Basically the main concern lies on how CRE is treated and approached in the context of a public mentality that trusts more in the examinations and job opportunities than on being educated for life. It is my contention that CRE needs to be viewed not as a body of knowledge and skills to be unpacked from the world of work, but as a way of guiding and leading towards critical judgment and intelligent choices based on clear concepts, values and beliefs. For this to work, it is necessary to have a new conception of education, mainly among the teachers, students, parents and stakeholders in which to be educated is not associated with either employment or passing the examinations at the end of the educational cycle. In relation to this, Kenya may need to restructure the assessment system so that it becomes more coherent and integrated into the education process. This is because as long as teachers and students are preoccupied with the passing of the examinations, the goals of education are unlikely to be fulfilled; it is only when this is done that CRE could secure its rightful place in secular education.

The education given must involve initiation into public modes of experience to be enabled "to be" relying on short lived outlook emanating from the country's social and economic system may distort our concentration on what education is all about.

The great bulk of changed may have to rely on negotiations based on persuasion and argumentation which make appeals to existing religious education programmes. Consequently, the key recommendation made is in regard to how function of producing a religiously education person. This recommendations made in the context of having all those involved in education clarify, avail and educate towards what objectives of an integrated RE would be. In this way, the misinformation of what they perceive CRE to do and not able to do would be cleared, as the subject would be in the curriculum mainly for its intrinsic value and not utilitarian value.

An integrated programme assumes a more educational concept in a secular plural society as opposed to CRE which has a bias towards a "religious activity" mainly interpreted with a Christian outlook(Hull, 1984 Newell, 1993) it is cru- 
cial to note that labelling the programme "religious education" allows it to draw upon itself aspects of educational studies religious plurality and secularity in Kenya. In this context, the move is towards a more functional programme that would enable those who have gone through it experiences to apply knowledge, understanding, skill and attitudes in the handling of ultimate reality quests and issue. Of course, one would expect the ideal approach and emphasis to be that which encompasses all social economic needs of the society, in this case, the approach may have aspects of "self actualisation" "self enablement" and "self reliance" these processes led to the student's being" under the issue of becoming religiously educated. Thus, the focus of the subject becomes educating in the area of religion to have a religiously educated student in a religiously pluralistic and secular Kenyan society.

\section{REFERENCES}

[1] Ajzen. I. 1988, Attitudes, Personality and Behaviour. Milton Keyres" Open University press

[2] Anderson J., 1970, The strangle for the School.Nairobi: Longman Kenya

[3] Ayot . H., 1986, Understanding Social Studies. Kenyatta University, Kenya and university of London institute of education

[4] Bogdan R.C and Biklen S.K.,1992,Qualitative Research for Education: An Introduction to theory and Methods. Boston, London: Ally and Bacon

[5] Burgess, R.G.,1986, "Education” IN Burgess, RG [Ed] \{1986\} Key variable in social . London Boston and Henley: Routledge and Kegan Paul

[6] Davin D.,1989, Gold Medal CRE KCSE Nairobi: McMillan, Kenya

[7] Deaux, K .,Dane F.C. and Wringtsman L.D.,1993, social psychology in the 90s . Pacific Grove California: books/cole publishing company

[8] Festinger, L., 1957, A Theory of Cognitive Dissonance USA: Row, Peterson \& company London: tailstock public

[9] Fraenkel, J., and Wallen. N., 1996,How to Design and Evaluate Research in Education. London New York: McGrawHill INC

[10] Francis, L.J.,1984,Monitoring the Christian development of the child. In occasional paper no two family, school and church in religious education

[11] Goenewegen T ,1988,CRE book three. Nairobi "Longman Kenya

[12] Goenewegen, T. and Githige, R.,1987, CRE book two. Nairobi "Longman Kenya

[13] Goenewegen, T., and Githige. R., and Mugambi J.,1986, CRE book one. Nairobi " Longman Kenya
[14] Goenewegen, T. and Wanjala T., 1989, Revision CRE book or KCSE. Nairobi "Heineman Kenya

[15] Hammersley, M., and Atkison, P., 1983, Ethnography principles in practice. London and New York; Routledge

[16] Hull, J.M., 1984, nature of religious education in J.M Sutclifgfe $\{$ ed $\}$ : A dictionary of religious education.London; SCM press Ltd

[17] Jahoda, M., and Warren. N., 1966:,Baltimore: penguin book inc

[18] Katz,D., 1960, The functional approach to the study of attitudes, public opinion quarterly, 24(2).163-204

[19] Kenya institute of education.,1992, Secondary Education Syllabus, Volume two . Nairobi literature Bureau

[20] Kerr, R., and Manyore. J., 1995, Top mark series, KCSE revision CRE. Nairobi: Kenya literature bureau, Kenya

[21] Levi, L., 1983, God meets us, book one. Nairobi; east African literature bureau, Kenya

[22] Levi, L .,1989,God meets us book Three. Nairobi "east African literature bureau, Kenya

[23] Likert, R .,1932, A technique for measurement of attitudes, archives of psychology No. 40

[24] Masolo, D.A.,1990, Gateway Secondary Revision CRE. Nairobi Longman Kenya

[25] May, T., 1993, Social Research; issues, Methods and Process. Buckingham: open university press

[26] Miles, M.B. and Huberman. M .,1994,An expanded sourcebook qualitative data analysis. Second edition. Thousand Oaks, London, new Delhi: sage publications

[27] Newell, M.R., 1993,An examination of policy and practice in religious education following the 1988 education act with special reference to the nature of religious education curriculum unpublished MA (R.E) kings college London, England

[28] Oppenheim, A.N., 1992,Questionnaire design interviewing and attitude measurement. New edition London Hainemann

[29] Oskamp, S.,1977, Attitudes and opinions. New jersey: prentice hall, Ibnc. Enlewoog cliggs

[30] Sarnoff., 1960, Psychoanalytic theory and social attitudes" public opinion quarterly, 24(2) 251-279

[31] Sherif, M. and Sherif .,C.E., 1967, Attitude as individuals' won categories: The social judgment involvement approach to attitude and attitude change. New York: john Wiley and sons INC

[32] Shipman, M.(ed)., 1976, The organization and impact of social research; six original case studies. London: Rutledge and Kegan Paul

[33] Thurstone, L.L.,1928, Attitudes can be measured. The American journal of sociology, XXXIII(4),529-554

[34] Varnon, P.E.,1964, Personality assessment; a critical survey London Methuen

[35] Welch, E. and Wild., 1988,God's people, book four Nairobi: oxford university, press Kenya 
[36] Welch, E. and Wild. J., 1987, God's people, book three Nairobi: oxford university, press Kenya

[37] Welch, E., and Wild. J., 1988,God's people, book one Nairobi: oxford university, press Kenya
[38] Welch,E., and Wild. J., 1988,God's people, book two Nairobi: oxford university, press Kenya

[39] Wiersma, W., 1989, Research methods in education. Itasca, Illinois: F.E Peacock publish ers, Inc 